\title{
Malgorzata Blaszke
}

Zachodniopomorski Uniwersytet Technologiczny w Szczecinie e-mail: malgorzata.blaszke@zut.edu.pl

\section{KORZYSTANIE Z NIERUCHOMOŚCI ROLNYCH} NA OBSZARACH CHRONIONYCH W OCENIE UŻYTKOWNIKÓW TYCH NIERUCHOMOŚCI

\section{USE OF AGRICULTURAL PROPERTY IN PROTECTED AREAS IN THE ASSESSMENT OF USERS OF THESE REAL ESTATES}

DOI: 10.15611/pn.2018.509.04

JEL Classification: D61, H61, H72, H82

\begin{abstract}
Streszczenie: $\mathrm{W}$ artykule zaprezentowano wyniki badań ankietowych przeprowadzonych w latach 2010-2015 na terenie województwa zachodniopomorskiego, dotyczących korzystania z nieruchomości rolnych położonych na obszarach objętych prawnymi formami ochrony przyrody. Celem badań było poznanie poglądów osób użytkujących nieruchomości rolne położone na obszarach chronionych na temat możliwości wykorzystania nieruchomości rolnych dla potrzeb prowadzenia działalności rolniczej, utrudnień w korzystaniu z tychże nieruchomości, a także motywów nabycia nieruchomości położonych na tym specyficznym terenie.
\end{abstract}

Słowa kluczowe: nieruchomość rolna, formy ochrony przyrody, użytkowanie nieruchomości, działalność rolnicza.

Summary: The article presents the results of the survey carried out in the period 2010-2015 in the West Pomeranian Voievodeship refering to using agricultural properities situated in nature conservation zonings. The aim of the research was to learn opinions of people using agricultural property situated in protected areas on the possibility of agriculture property management for the purposes of rendering agricultural activity, problems with using these properties and reasons of purchasing properties situated in this specific place.

Keywords: agricultural real estate, forms of nature protection, real estate use, agricultural activity.

\section{Wstęp}

W ostatnich latach można zauważyć rosnące zainteresowanie społeczności lokalnych ideą ochrony środowiska przyrodniczego; potwierdza to przegląd literatury 
na ten temat, której liczba stale wzrasta. Za najważniejszy cel nowej idei autorzy uważają budowę „,nowego ładu przy udziale mieszkańców Ziemi wraz z duchowością i etyką środowiskowej odpowiedzialności" [Perepeczko 2010, s. 157]. Zagadnienie postaw mieszkańców różnych regionów Polski wobec obszarów chronionych jest obecny w krajowych badaniach od wielu lat (zob. m.in. [Bałtromiuk (red.) 2001; Binswanger-Mkhize 2009; Ciechanowicz-McLean 2005; Dzun 2007; Kiełsznia 2010]). Jednakże w badaniach tych często pomija się właścicieli nieruchomości rolnych, ewentualnie występują oni jako kategoria analityczna wyodrębniona według miejsca zamieszkania. Według M. Halamskiej dzieje się tak, gdyż „definiowanie przestrzeni wiejskiej poprzez naturę i środowisko naturalne, pejzaż oraz dziedzictwo kulturowe legitymizuje użytkowanie tej przestrzeni przez całe społeczeństwo, a nie tylko mieszkańców wsi” [Halamska 2009]. Przyczyną braku zainteresowania badaczy posiadaczami nieruchomości rolnych położonych na obszarach cennych przyrodniczo może być pogląd o przyjaznej dla środowiska pracy rolników. Tymczasem nieruchomości rolne posiada coraz więcej osób, które nie użytkują ich rolniczo albo prowadzą działalność rolniczą, ale w dobie coraz większych osiągnięć nauki i techniki oraz przy niedostatku wiedzy i „moralności zawodowej” może ona przynieść środowisku naturalnemu więcej szkody niż pożytku [Krajewska 2002].

W województwie zachodniopomorskim, podobnie jak w całej Polsce, obszary chronione funkcjonują nie tylko w konkretnej rzeczywistości przyrodniczej, lecz także w pewnej rzeczywistości społecznej. Podstawowymi czynnikami mającymi wpływ na prowadzoną działalność rolniczą jest jakość użytków rolniczych oraz ich powierzchnia [Przygodzka 2006]. Użytkami rolnymi nazywamy grunty, które są lub mogą być wykorzystywane do produkcji rolniczej. Na strukturę użytków rolnych mają wpływ różnorodne czynniki, które najprościej można podzielić na:

- czynniki o charakterze przyrodniczym, np. występowanie na danym terenie elementów przyrody ożywionej lub nieożywionej cennych ze względów przyrodniczych, jakość gleby, poziom wody gruntowej;

- czynniki organizacyjno-ekonomiczne, np. system produkcji roślinnej, system produkcji zwierzęcej, typ produkcyjny.

Przedsięwzięcia dotyczące ochrony przyrody niejednokrotnie kolidują z działaniami prowadzonymi przez osoby użytkujące dane tereny. Problemy osób władających nieruchomościami rolnymi na obszarach o wybitnych walorach przyrodniczych dotyczą m.in. postawy wobec tworzenia konkretnej prawnej formy ochrony przyrody (akceptacja bądź negacja), potrzeby ich istnienia, formy i obowiązujących zasad ich ochrony oraz problemu własności prywatnej w obrębie obszarów chronionych (zarządzania i gospodarowania prywatną własnością, pozostającą pod prawną ochroną).

Celem przeprowadzonych badań było poznanie opinii osób użytkujących nieruchomości rolne położone na obszarach chronionych na temat możliwości wykorzystania nieruchomości rolnych dla potrzeb prowadzenia działalności rolniczej, utrudnień w korzystaniu z tych nieruchomości, a także motywów nabycia nieru- 
chomości położonych na tym specyficznym terenie. W celu poznania opinii osób będących właścicielami, użytkownikami wieczystymi nieruchomości położonych na obszarach chronionych oraz osób, które zbyły nieruchomości rolne położone na obszarach chronionych, posłużono się metodą sondażu diagnostycznego. Badanie zostało podzielone na dwa etapy:

Etap I - przeprowadzenie badania wśród nabywców nieruchomości rolnych położonych na obszarach chronionych w województwie zachodniopomorskim (grupa I).

Etap II - przeprowadzenie badania wśród osób, które przeniosły prawo własności lub prawo użytkowania wieczystego nieruchomości rolnych położonych na obszarach chronionych w województwie zachodniopomorskim na rzecz osób z grupy I (grupa II).

W obrębie sondażu diagnostycznego przeprowadzonego na etapie I zastosowano kwestionariusz ankiety, który przesłano drogą elektroniczną bądź pocztową do 1680 osób, które w okresie od 1 stycznia 2010 do 31 grudnia 2015 r. nabyły prawo własności bądź prawo użytkowania wieczystego nieruchomości rolnej położonej na obszarach chronionych. Zakres przestrzenny badania obejmował województwo zachodniopomorskie. Zamierzeniem autorki w etapie I było przeprowadzenie badania pełnego. Stopień zwrotu ankiet w tej grupie wyniósł 55\% (zwrócono 921 ankiet, z których do analizy przyjęto $860-51 \%$ wszystkich wysłanych). $\mathrm{W}$ drugim etapie badań kwestionariusze ankiet zostały przesłane do grupy osób stanowiących zbywców prawa własności bądź prawa użytkowania wieczystego nieruchomości rolnych położonych na obszarach chronionych.

Założono, że liczba zbywców nieruchomości rolnych (grupa II) jest identyczna z liczbą nabywców nieruchomości rolnych (grupa I) - 1680 osób. W obrębie etapu II zastosowano nieprobabilistyczną technikę doboru próby - metodę kuli śnieżnej. Osoby z grupy I zostały poproszone w kwestionariuszu ankiety o podanie informacji potrzebnych do odszukania osób, od których nabyły nieruchomości rolne. Odnalezieni dzięki osobom z grupy I zbywcy nieruchomości rolnych również zostali poproszeni o informacje o znanych im osobach, które zbyły nieruchomości rolne na obszarach chronionych. W wyniku zastosowania tej metody udało się uzyskać dane adresowe oraz w niektórych przypadkach adresy poczt elektronicznych 511 osób, do których zostały przesłane kwestionariusze ankiet. Stopień zwrotu w etapie II wyniósł 82,78\% (odesłano 423 ankiety).

\section{Rodzaj działalności prowadzonej na nieruchomościach rolnych objętych ochroną przyrody}

W powszechnym mniemaniu działalność rolnicza na obszarach cennych ze względów przyrodniczych nie jest bądź nie powinna być prowadzona (zob. m.in. [Laskowska 2011; Gawroński, Popławski 2007; Popławski 2010; Zielińska 2013]). Jednakże jest to przekonanie niesłuszne, wynikające z łączenia obszaru chronionego z 
parkiem narodowym bądź rezerwatem przyrody bez uświadamiania sobie istnienia także innych, mniej restrykcyjnych form ochrony krajobrazu i przyrody. Ustanowienie na danym obszarze ustawowej formy ochrony przyrody wiąże się ze wprowadzeniem ograniczeń mających na celu ochronę walorów przyrodniczych i krajobrazowych, a w pewnej mierze także kulturowych i historycznych.

Ograniczenia wprowadzane na obszarach chronionych są bardzo zróżnicowane w zależności od tego, jaką formą ochrony został objęty dany obszar i jakie są główne cele ochrony, ale tak naprawdę tylko objęcie ochroną ścisłą rzeczywiście oznacza zakaz prowadzenia działalności gospodarczej, w tym rolniczej. Ustanowienie ochrony ścisłej dotyczy przede wszystkim rezerwatów przyrody i parków narodowych. Na większości obszarów chronionych prowadzenie działalności rolniczej jest dopuszczalne i w różnych formach ma miejsce, co stanowi naturalną konsekwencję faktu, że w większości są to rejony o dużym odsetku gruntów rolnych. Oczywiście, nieracjonalna gospodarka rolna stanowi spore obciążenie dla środowiska przyrodniczego, lecz trudno sobie wyobrazić, by nie była prowadzona w ogóle.

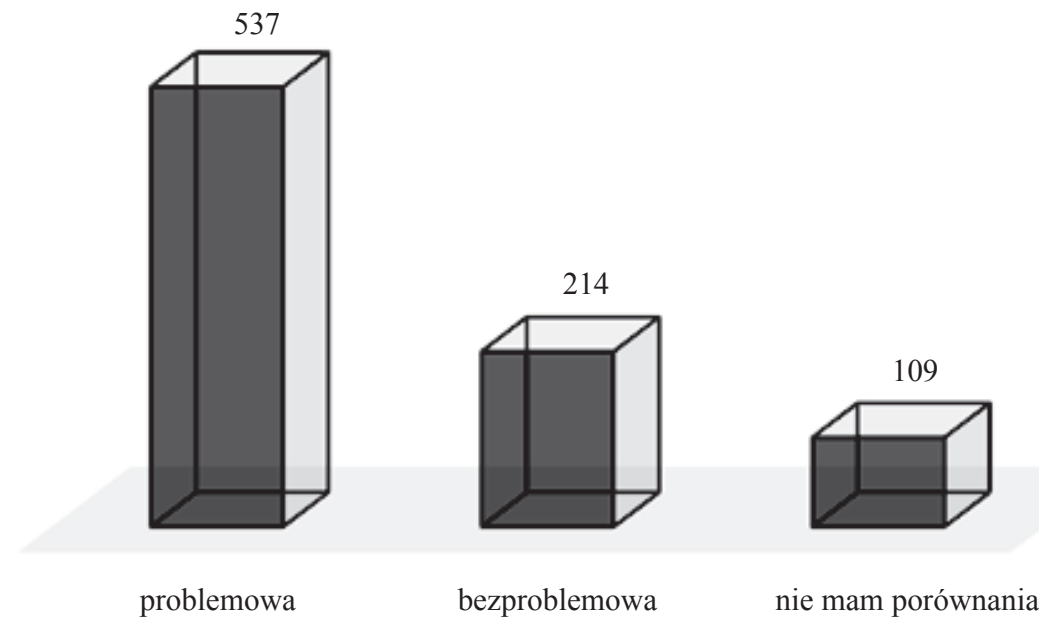

Rys. 1. Trudność prowadzenia działalności rolniczej na obszarach chronionych

Źródło: opracowanie własne na podstawie badań ankietowych.

Osoby posiadające nieruchomości rolne na obszarach objętych ustawową formą ochrony przyrody uważają, że prowadzenie działalności rolniczej na tych terenach jest utrudnione. Wspomnianych trudności dopatrują się właśnie we wszelkiego rodzaju ograniczeniach i zakazach obowiązujących na tych terenach; uważają, że są one zbyt restrykcyjne. Około $24 \%$ ankietowanych uznało, że prowadzenie działalności rolniczej na obszarach chronionych jest bezproblemowe, choć specyficzne ze względu na utrudnienia związane z ekologiczną uprawą roślin i hodowlą zwierząt. Jednakże trudności w prowadzeniu działalności rolniczej są do przezwyciężenia 
i nie mają zasadniczego wpływu na koszty produkcji. Ponad 16\% ankietowanych nie posiadało do tej pory nieruchomości rolnych poza obszarami chronionymi, nie mogą więc porównać prowadzenia działalności rolniczej na obszarach innych niż chronione. Osoby te przyzwyczajane są do dodatkowych restrykcji i nie uważają, by miały one zasadniczy wpływ na jakość prowadzonej przez nich produkcji rolniczej.

nie prowadzę produkcji rolniczej

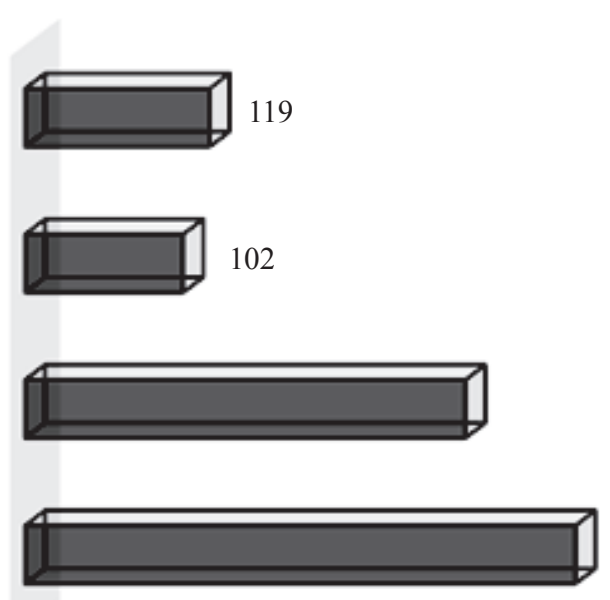

rolnictwo ekologiczne

Rys. 2. System gospodarki rolnej stosowany przez badane osoby z grupy I

Źródło: opracowanie własne na podstawie badań ankietowych.

Jedno z pytań skierowanych do respondentów dotyczyło stosowanego w gospodarstwie rolnym systemu gospodarki rolnej. Zdecydowana większość ankietowanych przyznaje się do stosowania systemu rolniczego konwencjonalnego - ok. $74 \%$. W odniesieniu do rolnictwa konwencjonalnego wybierano tylko dwa rodzaje: rolnictwo ekstensywne $-56 \%$ oraz rolnictwo intensywne $-44 \%$. Rolnictwo konwencjonalne charakteryzuje się ukierunkowaniem na maksymalizację zysku, osiąganego dzięki dużej wydajności roślin i zwierząt uzyskanej poprzez zastosowanie technologii produkcji opartych na dużym zużyciu przemysłowych środków produkcji i bardzo małych nakładach robocizny [Popławski 2011]. Alternatywny dla rolnictwa system gospodarowania - rolnictwo ekologiczne stosuje tylko ok. $12 \%$ ankietowanych osób. Rolnictwo ekologiczne polega na stosowaniu środków naturalnych, nieprzetworzonych technologicznie. Podstawową zasadą w rolnictwie ekologicznym jest odrzucenie w procesie produkcji żywności środków chemii rolnej, weterynaryjnej i spożywczej [Popławski 2011].

Kolejną grupę respondentów stanowiły osoby, które na nieruchomościach rolnych prowadzą inną niż rolnicza działalność - 14\%. 
uprawy rolne połączone $\mathrm{z}$ chowem i hodowlą zwierząt chów i hodowla zwierząt

rozmnażanie roślin

uprawa roślin wieloletnich

uprawy rolne inne niż wieloletnie

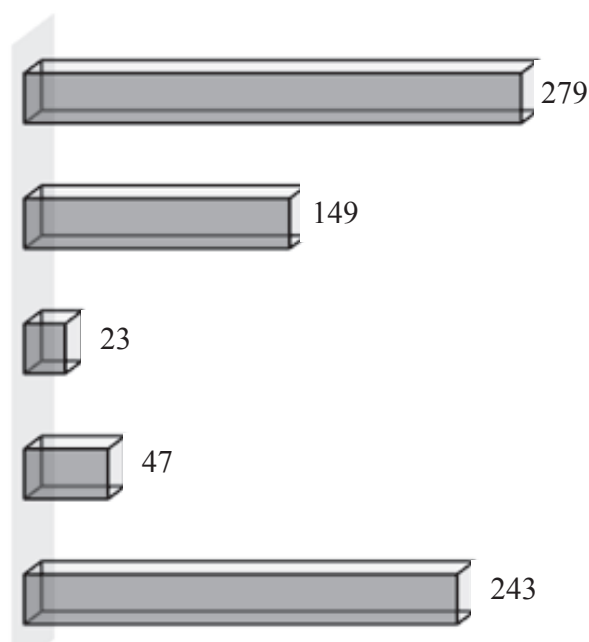

Rys. 3. Kierunki produkcji rolniczej realizowane przez badane osoby

Źródło: opracowanie własne na podstawie badań ankietowych.

W kolejnym pytaniu grupa 741 respondentów prowadzących na nieruchomościach rolnych będących w ich władaniu działalność rolniczą miała wskazać główne kierunki produkcji rolniczej. Największą grupę stanowiły osoby prowadzące działalność mieszaną (połączenie produkcji roślinnej z chowem i hodowlą zwierząt) $32 \%$. Kolejna specjalizowała się w uprawie roślin innych niż wieloletnie $-28 \%$, z czego najliczniejszą grupę stanowili rolnicy zajmujący się uprawią zbóż - 57\% oraz uprawą warzyw $-43 \%$.

Chów i hodowla zwierząt jest trzecim rodzajem produkcji, w której specjalizowały się osoby posiadające nieruchomości rolne na obszarach chronionych $17 \%$. W przypadku takiej produkcji największy udział przypadał hodowcom bydła mlecznego $-42 \%$, pozostały kształtował się następująco:

- chów i hodowla świń - 34\%,

- chów i hodowla drobiu (z nastawieniem na produkcję jaj) - 19\%,

- chów i hodowla pozostałego bydła (produkcja nasienia bydlęcego) $-2 \%$,

- chów i hodowla kóz (produkcja mleka koziego) - 2\%,

- chów i hodowla koni i innych zwierząt koniowatych - $1 \%$.

Osoby, które zdecydowały się na kupno nieruchomości rolnych położonych na obszarach cennych pod względem przyrodniczym, nie zawsze prowadzą na nich typowo rolniczą działalność. Większość prowadzi gospodarstwa agroturystyczne $-44,5 \%$ oraz działalność rekreacyjną, polegającą m.in. na organizowaniu przejażdżek konnych, rowerowych lub wycieczek krajoznawczych - 35\% (rys. 4). 
działalność rekreacyjna

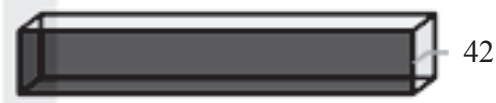

agroturystyka

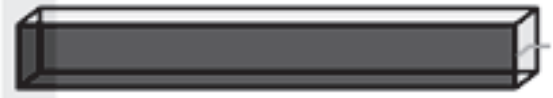

działalność usługowa związana z wyżywieniem

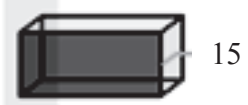

inna

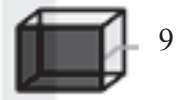

Rys. 4. Inna działalność prowadzona na użytkowanych nieruchomościach rolnych

Źródło: opracowanie własne na podstawie badań ankietowych.

nie była prowadzona

produkcja rolnicza

rolnictwo ekologiczne

rolnictwo intensywne

rolnictwo ekstensywne

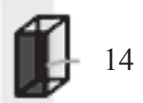

5

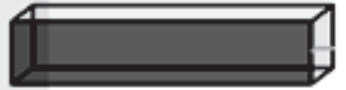

141

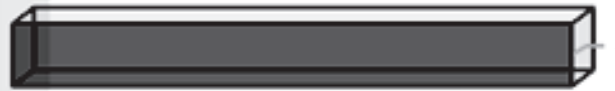

Rys. 5. System gospodarki rolnej stosowany przez osoby, które zbyły nieruchomości rolne - grupa II Źródło: opracowanie własne na podstawie badań ankietowych.

Zdecydowana większość osób, które zbyły nieruchomości rolne położone na obszarach cennych przyrodniczo, przyznaje, że stosowało system rolnictwa konwencjonalnego - ok. 95\%. W ramach rolnictwa konwencjonalnego realizowane były 
jego dwa rodzaje: rolnictwo ekstensywne $-65 \%$ oraz rolnictwo intensywne $-35 \%$. Rolnictwo ekologiczne prowadziło tylko ok. $1 \%$ badanych osób, a 3\% nie prowadziło produkcji rolniczej.

Tabela 1. Kierunki produkcji rolniczej realizowane przez badane osoby

\begin{tabular}{|l|c|}
\hline \multicolumn{1}{|c|}{ Kierunki produkcji rolniczej } & Liczba osób \\
\hline Uprawy rolne połączone z chowem i hodowlą zwierząt & 191 \\
\hline Chów i hodowla zwierząt & 112 \\
\hline Uprawy inne niż wieloletnie & 67 \\
\hline Uprawa roślin wieloletnich & 32 \\
\hline
\end{tabular}

Źródło: opracowanie własne na podstawie badań ankietowych.

W kolejnym pytaniu grupa 402 respondentów prowadzących na nieruchomościach rolnych działalność rolniczą miała wskazać główne kierunki produkcji. Największą grupę stanowiły osoby prowadzące działalność mieszaną (połączenie produkcji roślinnej z chowem i hodowlą zwierząt) $-47 \%$. Kolejna specjalizowała się wyłącznie w chowie i hodowli zwierząt - 28\%; największy udział przypadał hodowcom drobiu (produkcja jaj) - 54\% (61 osób).

agroturystyka

działalność usługowa związana z wyżywieniem

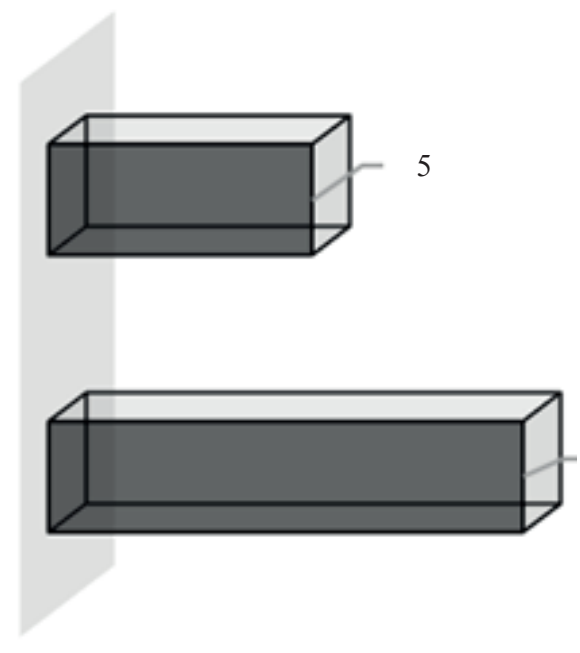

Rys. 6. Inna działalność prowadzona na użytkowanych nieruchomościach rolnych przez osoby z grupy II

Źródło: opracowanie własne na podstawie badań ankietowych.

Niewielka liczba osób spośród zbywców nieruchomości rolnych położonych na obszarach chronionych nieprowadzących produkcji rolniczej zajmowała się przede wszystkim działalnością związaną z wyżywieniem - 64\%. Najmniejszy udział miały osoby prowadzące działalność agroturystyczną - 36\%. 


\section{Konsekwencje posiadania nieruchomości rolnych na obszarach chronionych}

W wypowiedziach medialnych często spotyka się opinie osób zaangażowanych $\mathrm{w}$ ochronę przyrody, które $\mathrm{z}$ chęcią wyeliminowałyby lub w znacznym stopniu ograniczyły każdą działalność gospodarczą prowadzoną na terenie obszarów chronionych, nie wydaje się to jednak realne. Co więcej, taka inicjatywa nie spotkałaby się zapewne z przychylnością ze strony lokalnego społeczeństwa, postrzegającego często objęcie danego obszaru ochroną jako źródło wyłącznie kłopotów. W obecnych czasach wydaje się, że częścią strategii ochrony przyrody w Polsce powinno być nie tylko wykluczanie zagrażających środowisku przejawów działalności ludzkiej z terenów najcenniejszych przyrodniczo, lecz także umiejętne integrowanie aktywności gospodarczej z celami ochronnymi tam, gdzie działalność gospodarcza jest prawnie dopuszczona. Ważne jest, aby przedsiębiorcy działający w rejonach o wysokich walorach przyrodniczych lub krajobrazowych zdawali sobie sprawę z wpływu, jaki wywierają na środowisko, ponieważ od ich świadomości ekologicznej zależy stan przyrody. Gospodarowanie na obszarach objętych prawną formą ochrony przyrody nie pozostaje również bez wpływu na możliwości rozwoju [Perepeczko 2010]. Konieczność prowadzenia działalności rolniczej na terenach objętych ochroną przyrody jest dla niektórych osób wyzwaniem z uwagi na dostrzeganie wyłącznie negatywnych skutków restrykcji wprowadzonych na obszarach cennych przyrodniczo.

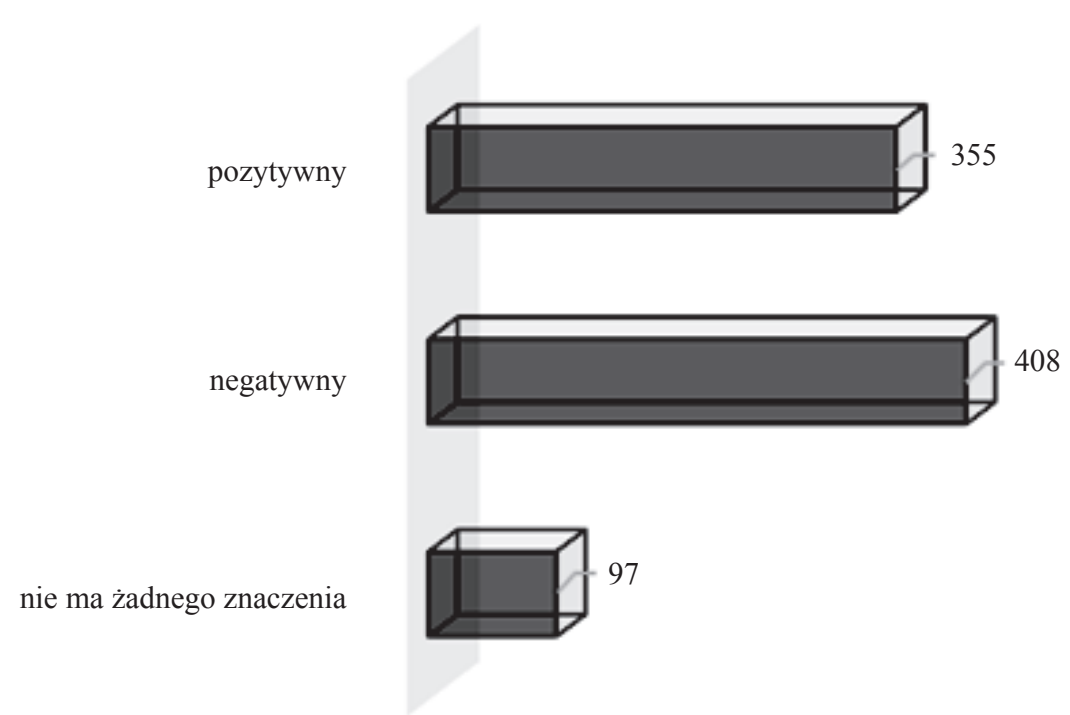

Rys. 7. Opinia osób posiadających nieruchomości rolne na temat sąsiedztwa obszarów chronionych Źródło: opracowanie własne na podstawie badań ankietowych. 
Jak wynika z badań przeprowadzonych wśród 860 osób posiadających nieruchomości rolne na obszarach chronionych, ok. 47\% uważa, że sąsiedztwo obszarów chronionych wpływa negatywnie na działalność rolniczą i w znacznym stopniu obniża jej jakość. Pozytywny wpływ obszarów chronionych dostrzegło 41\% osób, a dla $12 \%$ ustanowienie formy ochrony przyrody w sąsiedztwie ich nieruchomości nie ma żadnego znaczenia.

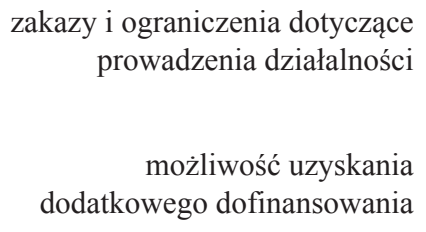

rozwój regionu

rozwój turystyki

atrakcyjne położenie

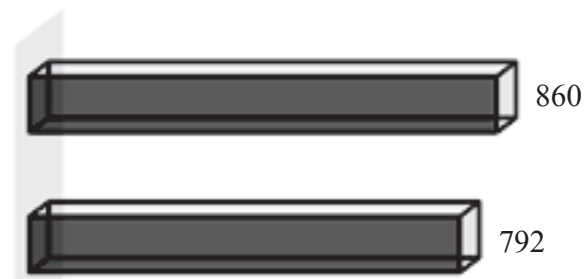

860

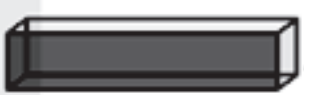

497

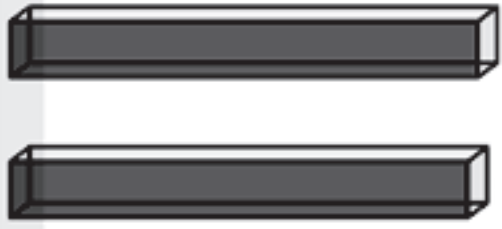

860

842

Rys. 8. Asocjacja obszarów chronionych u osób posiadających nieruchomości rolne na tych obszarach

Źródło: opracowanie własne na podstawie badań ankietowych.

Jedno z pytań zamieszczonych $\mathrm{w}$ ankiecie dotyczyło pierwszego skojarzenia respondentów, które nasuwa im się w związku z objęciem danego obszaru ochroną przyrody. Zgodnie z danymi na rysunku 8 . wszystkie ankietowane osoby utożsamiają obszary chronione $\mathrm{z}$ ograniczeniami i zakazami dotyczącymi prowadzenia działalności gospodarczej, w tym rolniczej. Jednakże te same osoby wskazały, że uznanie danego terenu za obszar cenny pod względem przyrodniczym powinno sprzyjać szybkiemu rozwojowi turystyki w gminie, m.in. dzięki atrakcyjnemu położeniu; 92\% ankietowanych osób widzi w posiadaniu nieruchomości na obszarach chronionych szansę na uzyskanie dodatkowego dofinansowania z programów rolno-środowiskowych. 


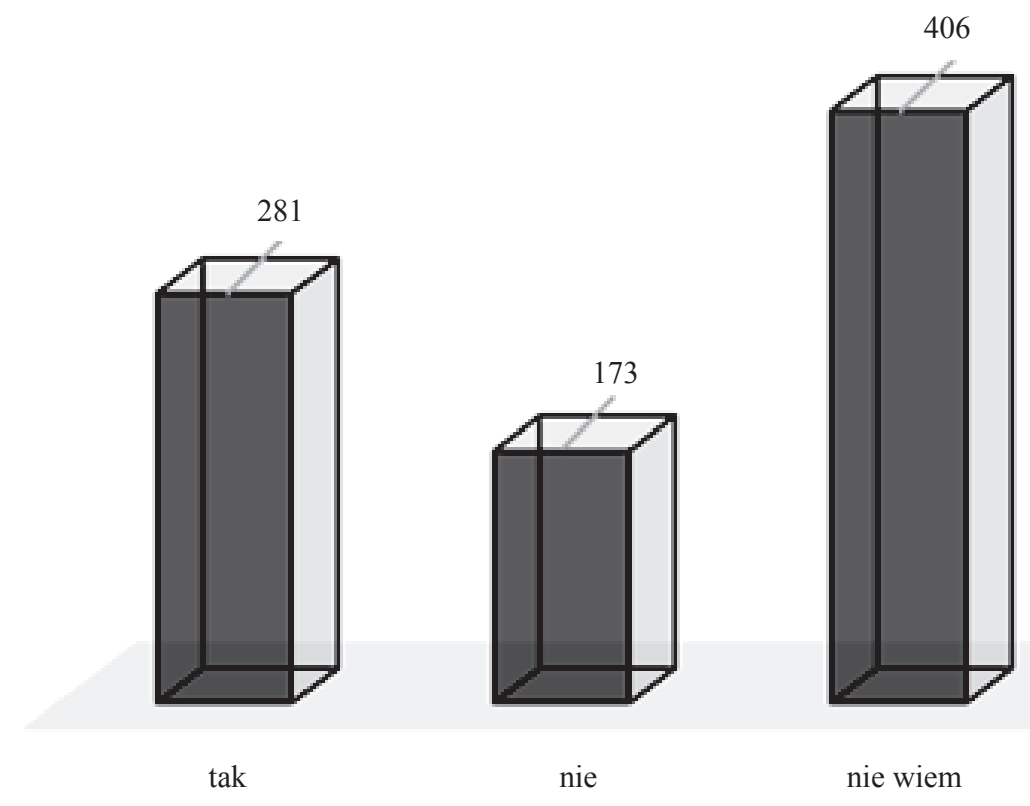

Rys. 9. Możliwości wymiany doświadczeń w prowadzeniu działalności na obszarach chronionych

Źródło: opracowanie własne na podstawie badań ankietowych.

Jedno z pytań dotyczyło możliwości wymiany doświadczeń z osobami prowadzącymi od dłuższego czasu działalność gospodarczą, w tym rolniczą, na obszarach objętych różnymi formami ochrony przyrody; $67 \%$ ankietowanych stwierdziło, że albo nie korzysta z takiej możliwości (20\%), albo nie wie, iż taka możliwość w ogóle istnieje (47\%). Tylko ok. 33\% osób oświadczyło, że na terenie gminy istnieje możliwość udziału w spotkaniach przeznaczonych dla osób prowadzących działalność rolniczą na obszarach chronionych. Część z nich stwierdziło, że spotkania odbywają się cyklicznie, a ich tematyka jest pomocna w usprawnianiu działalności.

Tabela 2. Bariery rozwoju działalności rolniczej na obszarach chronionych

\begin{tabular}{|l|c|}
\hline \multicolumn{1}{|c|}{ Ograniczenia } & Liczba osób \\
\hline Migracje ludzi młodych do miast & 325 \\
\hline Niska dochodowość rolnictwa & 112 \\
\hline Niskie dochody mieszkańców & 504 \\
\hline $\begin{array}{l}\text { Brak informacji i szkoleń nt. Składania wniosków i możliwości uzyskiwania } \\
\text { dopłat w zakresie realizacji programów rolno-środowiskowych }\end{array}$ & 409 \\
\hline Ochrona przyrody i sąsiedztwo obszarów chronionych & 82 \\
\hline Brak działań promujących produkty lokalne & 729 \\
\hline
\end{tabular}

Źródło: opracowanie własne na podstawie badań ankietowych. 
Osoby posiadające nieruchomości rolne na obszarach objętych jedną lub kilkoma formami ochrony przyrody utożsamiają z nimi różnego rodzaju ograniczenia i przeszkody. Społeczności lokalne widzą w tworzeniu obszarów chronionych przyczynę m.in. uzyskiwania niskich dochodów przez mieszkańców, niskiej dochodowości z produkcji rolniczej oraz migracji osób $\mathrm{w}$ wieku produkcyjnym do miast.

Ankietowane osoby często odnosiły się do braku działań gmin dotyczących promowania lokalnych produktów pochodzących z rolnictwa prowadzonego na obszarach cennych przyrodniczo, jak również braku promocji działalności dodatkowej, np. agroturystyki czy różnych form rekreacji.

\section{Zakończenie}

Podsumowując przeprowadzone badania, należy stwierdzić, że możliwości gospodarowania na nieruchomościach rolnych stanowią niedostatecznie zanalizowany obszar, o potencjalnie dużych możliwościach badawczych.

Objęcie nieruchomości rolnej prawną formą ochrony przyrody może wpływać na podjęcie decyzji o zmianie sposobu użytkowania nieruchomości; nie polega ona na wyłączeniu gruntów z produkcji rolniczej, lecz na zmianie koncepcji użytkowania gruntów rolnych. 14\% osób posiadających nieruchomości rolne na obszarach cennych przyrodniczo zdecydowało się na prowadzenie, obok produkcji typowo rolniczej, dodatkowej działalności pozwalającej wykorzystać walory przyrodnicze, np. turystycznej, rekreacyjnej, wypoczynkowej. Mogłoby się wydawać, że osoby posiadające nieruchomości rolne na obszarach chronionych będą nastawione na rolnictwo ekologiczne, jednakże tylko ok. $1 \%$ badanych osób przyznaje się do stosowania tego systemu rolnego.

Osoby objęte badaniem, które zdecydowały się na zbycie nieruchomości rolnych położonych na obszarach chronionych, argumentowały swoją decyzję przede wszystkim: korzystną ceną $-84 \%$, położeniem na obszarach chronionych $-48 \%$, sąsiedztwem obszarów chronionych - 24\%. Badane osoby mogły wybrać maksymalnie dwie odpowiedzi spośród podanych lub podać własną.

Wyniki badań przeprowadzonych wśród osób posiadających nieruchomości rolne na obszarach chronionych wykazały, że ok. $47 \%$ z nich uważa, iż sąsiedztwo obszarów chronionych wpływa negatywnie na prowadzoną działalność rolniczą i w znacznym stopniu obniża jej jakość. Pozytywny wpływ obszarów chronionych dostrzegło $41 \%$ osób, a dla $12 \%$ ustanowienie formy ochrony przyrody w sąsiedztwie ich nieruchomości nie ma żadnego znaczenia. Te same badania przeprowadzone wśród osób, które zbyły nieruchomości rolne położone na obszarach chronionych, wykazały, że w $90 \%$ przypadków sąsiedztwo obszarów chronionych wpływa negatywnie na prowadzoną działalność rolniczą i w znacznym stopniu obniża jej jakość. Pozytywny wpływ dostrzegło tylko $9 \%$ zbywających.

Osoby uczestniczące w badaniu przyjmują, że prowadzenie działalności rolniczej na obszarach chronionych jest utrudnione (62\%). Trudności dopatrują się 
w ograniczeniach i zakazach obowiązujących na tych terenach; uważają, że są one zbyt restrykcyjne. Pozostałe osoby twierdzą, że prowadzenie działalności rolniczej na tych obszarach jest specyficzne, a wszelkie trudności są do przezwyciężenia i nie mają istotnego wpływu ani na jakość prowadzonej działalności, ani na koszty produkcji.

\section{Literatura}

Bałtromiuk A. (red.), 2001, Gospodarowanie na obszarach chronionych, Wydawnictwo Uniwersytetu w Białymstoku, Białystok.

Binswanger-Mkhize H.P., 2009, Agricultural Land Redistribution: Toward Greater Consensus, The International Bank for Reconstruction and Development/The World Bank, Washington D.C.

Chmielewski T.T., Węgorek T., 2003, Rolnicza przestrzeń produkcyjna a różnorodność biologiczna, [w:] R. Andrzejewski, A. Weigle (red.), Różnorodność biologiczna Polski, Narodowa Fundacja Ochrony Środowiska, Warszawa.

Ciechanowicz-McLean J., 2005, Obrót nieruchomościami rolnymi na obszarach prawnej ochrony przyrody, Studia Iuridica Agraria, t. 4.

Dzun W., 2007, Gospodarowanie zasobami ziemi rolnej w Polsce, Wieś i Rolnictwo, nr 2, Warszawa.

Gawroński K., Popławski Ł., 2007, Problemy gospodarki przestrzennej na obszarach ekologicznie chronionych na przykładzie Popradzkiego Parku Krajobrazowego, Acta Scientiarum Polonorum, Administratio Locorum, s. 1-2.

Halamska M., 2009, Uwagi o naturze wiejskości i sposobie jej definiowania, [w:] G. Gorzelak, M.S. Szczepański, W. Ślęzak-Tazbir (red.), Człowiek-miasto-region. Związki i interakcje, Wydawnictwo Scholar, Warszawa.

Kiełsznia M., 2010, Funkcjonowanie gospodarstw rolnych na obszarach chronionych $w$ Polsce na przykładzie Kampinoskiego Parku Narodowego, Folia Pomeranae Universitatis Technologiae Stetinensis, Oeconomica, nr 277 (28), s. 21-26.

Krajewska H., 2002, Parki krajobrazowe jako przedmiot konfliktów w gospodarce przestrzennej, Biuletyn Parków Krajobrazowych Wielkopolski, z. 8 (10).

Laskowska E., 2011, Inwestowanie na rynku gruntów rolnych w Polsce, Roczniki Nauk Rolniczych, Seria G, t. 98, z. 3, Warszawa.

Perepeczko B., 2010, Postawy i oczekiwania proekologiczne mieszkańców wsi obszarów chronionych, Wieś i Rolnictwo, nr 1 (146), s. 157.

Popławski Ł., 2010, Instrumenty ekonomiczne a rozwój przedsiębiorczości i agrobiznesu na obszarach chronionych - wybrane problemy, Roczniki Naukowe SERiA, t. 12, z. 2.

Popławski Ł., 2011, Ziemia w działalności gospodarczej - aspekt teoretyczny, Roczniki Naukowe SERiA, t. 13, z. 8.

Przygodzka R., 2006, Fiskalne instrumenty wspierania rozwoju rolnictwa - przyczyny stosowania, mechanizmy i skutki, Wydawnictwo Uniwersytetu w Białymstoku, Białystok, s. 26.

Zielińska A., 2013, Gospodarowanie na obszarach przyrodniczo cennych $w$ Polsce w kontekście rozwoju zrównoważonego, Wydawnictwo Uniwersytetu Ekonomicznego we Wrocławiu, Wrocław. 